\title{
LATE PUERPERIUM AND THE NEW REPRODUCTIVE CYCLE IN COWS WITH REGARD TO RESTORATION OF THEIR OVARIAL ACTIVITY, ESTRUS AND THE FIRST POSTPARTAL OVULATION
}

\author{
Z. VLČEK \\ Department of Farm Animal Reproduction and Surgery, University of Veterinary Science,
} 61242 Brno

Received March 1, 1981

\begin{abstract}
Vlček Z.: Late Puerperium and the New Reproductive Cycle in Cows with Regard to Restoration of their Ovarial Activity, Estrus and the First Postpartal Ovulation. Acta vet. Brno, 51, 1982: 75-80.

The time sequence of uterine involution, regression of the corpus luteum graviditatis, restoration of the ovarial activity and symptoms of estrus and the first postpartal ovulation were followed in 282 Bohemian Pied cows.

The involution of the reproductive organs inspected by external, vaginal and rectal examination followed the usual pattern. More pregnancies were placed in the right uterine horn. A pea-sized regressive corpus luteum graviditatis was found in a portion of examined cows on days $12-14$ post partum, later no more corpora lutea were exactly identifiable. In several cows as soon as on days $15-17$ post partum, in majority of animals on days 18-20, growth of follicles was observed. The majority of cows showed signs of the jollicular phase of the reproductive cycle in the fourth week after parturition and some animals were in metestrus or diestrus. Morphological changes in the first cycle were more frequently observed on the left ovary and on the side of the previously non-pregnant uterine horn.
\end{abstract}

Involution, uterus, ovary, vaginal mucosa, secretions.

Great attention has been paid to physiology of puerperium in cows as well as to etiology, diagnosis and prevention of pathological conditions complicating the course of puerperium and impairing future fertility. The present study reports on results of a complex examination of puerperal cows obtained under large-scale farm conditions. The aim of the research project is to successfully monitor the reproductive process in cattle.

New data have been added to the knowledge of the course of puerperium in cows, including information about mechanisms of puerperal involution of reproductive organs, regression of the corpus luteum graviditatis, restoration of the reproductive cycle after parturition (Wagner et al. 1969; Wagner and Hansel 1969; Kudláč and Vlček 1975; Kudláč 1975; Laktiš 1979). The course of involutional process was studied in detail by Gier and Marion (1968), factors affecting the regression of c. luteum by Marion et al. (1968), the bacterial content of the uterus by Lloyd et al. (1968). Regression of corpus luteum graviditatis was investigated also by Wohanka (1961) and others. Uterine involution and follicular activity of the ovaries in puerperium with regard to fertility disorders was studied by Bostedt et al. (1976), Arbeiter (1976), Buchholz and Busch (1977), Rüsse (1968). Relationships between the course of puerperium and readiness for a new conception was followed by Bach (1974). The relationship between the course of puerperium, milk yield, lactation curve and conception rate was investigated by Buchholz and Jerichow (1977). The aim of these and many other papers was to optimalize and shorten the course of puerperium and to ensure a high conception rate in cows through an active control of puerperium and, if necessary, by means of therapy. 


\section{Materials and Methods}

Clinical examinations were performed in 282 Bohemian Pied cows in late puerperium and at the beginning of a new reproductive cycle. The clinical examination was focused on the course of uterine involution, regression of the corpus luteum graviditatis, restoration of ovarial activity, signs of estrus and the first postpartal ovulation and consisted of external, vaginal and rectal inspection.

The examinations were performed in cows on days $12-14,15-17,18-20,21-25,26-30$, $31-40,41-50,51-60,61-70,71-80$ after parturition.

At the same time the degree of bacterial contamination of the cervical mucus was studied along with analysis of the bacterial flora. The parameters were observed both in cows showing no cyclical changes after parturition and in those with restored reproductive cycle. Results of the bacteriological examinations and sensitivity tests of isolated microbes to antibiotics will be presented in the following communication.

\section{Results and Discussion}

The pattern of involutional changes of the reproductive organs of cows examined in the present study did not differ from that described by other authors and in our previous observations. On days $12-14$ post partum the vaginal mucosa was mostly pale pink, covered with a thicker mucus, the external os of the uterine cervix still slightly open. The cervical canal was almost closed at following examinations. In the vagina, dark red or sanguinolent brown secretion with brown cruors was often present, in several cows the mucus was turbid and contained flocks, in some animals secretion of mucopurulent appearance was found. The cervix was still dislocated from the medial line and more distally, the external os and portio vaginalis were enlarged, often petechiae and larger old haemorrhagiae, brown or dark red in colour. The uterus was situated rather deep in the abdominal cavity, in several cows still hardly to locate and it showed a marked assymetry of the cornua. The width of the previously pregnant horn was about 3 to 5 fingers, that of non-pregnant horn less than 3 fingers. The vaginal examination on days $15-17$ post partum revealed no differences as against the first examination. The vaginal portion of the cervix was still in a more horizontal position and its external os was slightly open. The present haemorrhagiae were brown in colour. The brownish secretion contained debris and small brown cruors in some animals. In cows with restored follicular activity the secretions were blood-tinged. The size of uterine horns was only slightly smaller; the size of uterus decreased very slowly in late puerperium, showing considerable individual variations.

On days $18-20$ after parturition, the vaginal mucosa was pale, covered with small amounts of secretions in some animals. In cows before proestrus the amount of mucus increased. Portio vaginalis uteri was still situated more distally, or it was deviated from the medial line. The external os slightly open, the secretion mucous, with a mild brownish-red colour. The previously pregnant uterine horn further diminished in size to a mean width of more than 3 fingers, the non-pregnant horn to more than 2 fingers.

Later the appearance of the vaginal mucosa and portio vaginalis uteri were closely connected to the phase of the restored sexual cycle. Uterine involution proceeded so that only a slight assymetry of the uterine horns was perceptible, and in part of the cows the previously pregnant horn could not be detected any more by rectal exploration. On days $21-30$ the vaginal findings were largely dependent upon the phase of the reproductive cycle. Mostly the follicular 


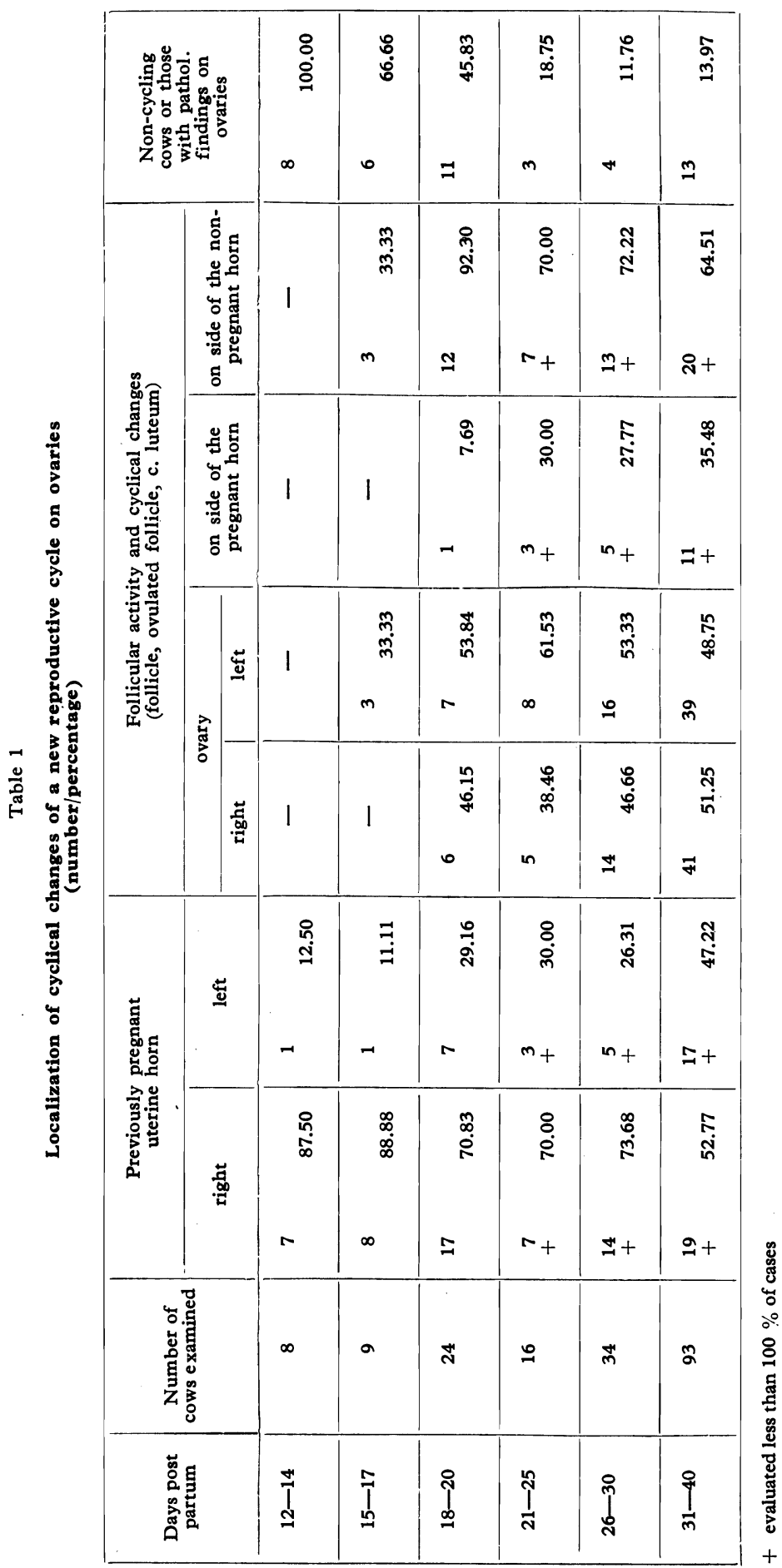




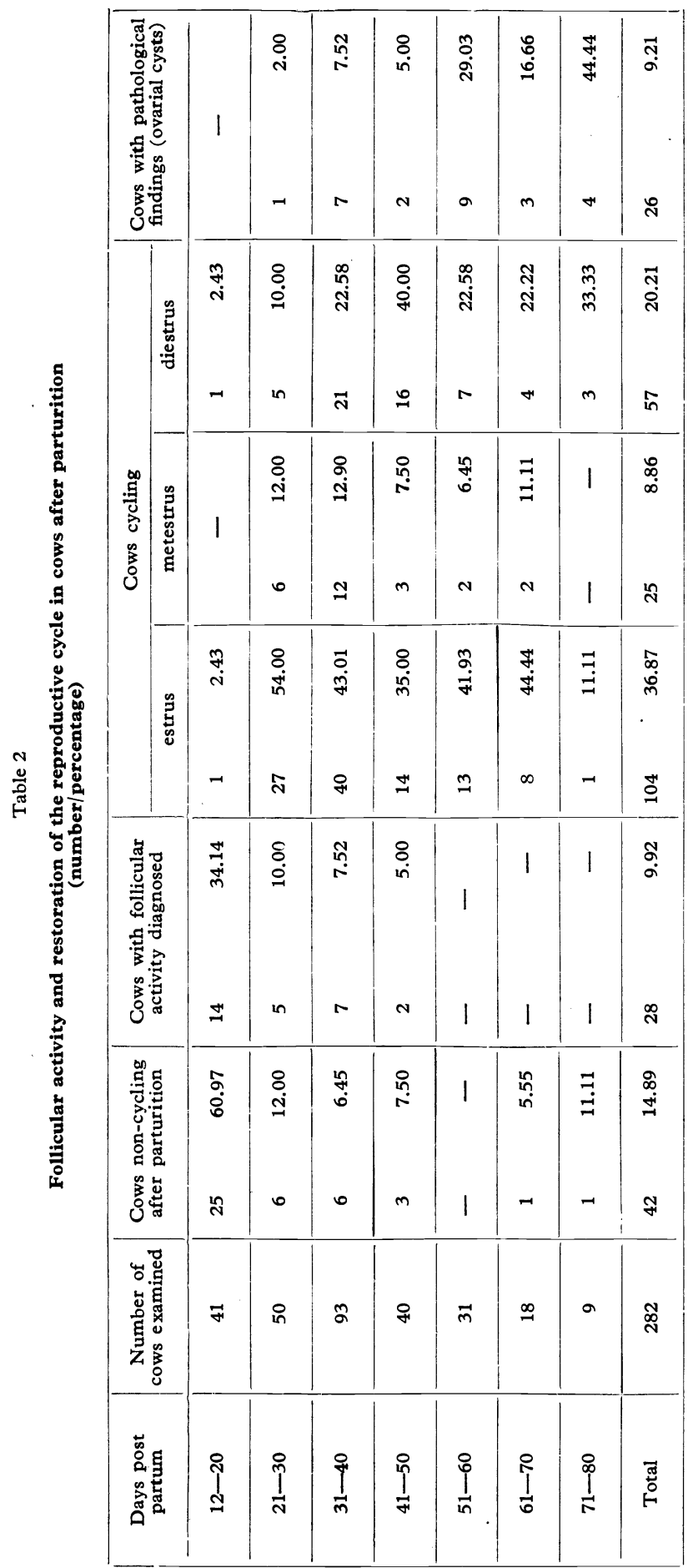

phase was diagnosed (proestrus or estrus). Palpation of the uterus confirmed an advanced stage of involution with only small assymetry of uterine horns (the pregnant horn was $2-3$ fingers thick, the other one between 1 and 2 fingers thick). In some animals no differences were found.

Table 1 shows that the majority of pregnancies were placed in the right uterine horn. In the first days of late puerperium (12-14 days post partum), the rectal exploration revealed a pea-sized regressive corpus luteum on the side of the pregnant uterine horn. Later its size diminished and from day 15-17 it was not identified in majority of animals. In several cows with non-identifiable corpus luteum the presence of a residuum was assumed from a smaller prominence and thicker consistency of one ovarial pole.

Table 1 also shows the localization of the cyclical changes of the restored reproductive cycle. Our results confirm the data of other writers on a rapid onset and increase in follicular activity of the ovaries after parturition. In cows employed in our study, follicular growth was diagnosed in few animals on days $15-17$, in a larger portion of cows on days 18-20 after parturition. However, the majority of cows was still in the phase of sexual inactivity. In the 
fourth week after parturition the majority of cows showed marked signs of the follicular phase (proestrus or estrus) and a few had already ovulated (i.e. were in metestrus or diestrus). Between days 31-40 the number of cows that had already ovulated further increased. Table 1 shows that the cyclical changes of the first postpartal cycle were found on the ovary of the previously non-pregnant side of the body. Hence, in our animals the changes were more often diagnosed on the left ovary. The first post partal ovulation often shows no signs of estrus (Kudlác and Vlček 1970) and the animals are usually not inseminated. Although there is no evidence of a regular interchange of both ovaries at ovulation, we found a higher frequency of ovulation on the right ovary at the second postpartal heat when the majority of cows are inseminated. Similarly, the conceptus is localized again in the right uterine horn at the early diagnosis of pregnancy.

Table 2 shows the restoration of reproductive cycle according to its phases, diagnosed by external, vaginal and rectal examination. It also shows pathological findings such as ovarial cysts etc. Our data confirm the fact that the reproductive cycle is restored between days 20 and 30 post partum in majority of cows. Nevertheless, the involutional changes of the uterus and ovarial activity are largely affected by the lengt of lactation period, nutrition, age, season of the year, husbandry practices and other factors.

\section{Pozdní puerperium a nový reprodukční cyklus krav se zřetelem k obnovení ovariální aktivity, říje a první postpartální ovulaci}

U 282 krav českého strakatého skotu byl v pozdním puerperiu a na začátku nového reprodukčního cyklu $(12-80$ dnù po porodu) sledován postup involuce dělohy, regrese graviditního žlutého tělíska, obnovení ovariální aktivity, projevy řije a první postpartální ovulace.

Dynamika involučních změn na pohlavních orgánech, zjistitelných zevním, vaginálním a rektálním vyšetřením, nevybočovala $\mathrm{z}$ rámce publikovaných poznatkủ. Častěji byl obřezlý pravý děložní roh. 12.-14. den po porodu bylo u části krav prokazatelné regresívní graviditní žluté tělísko velikosti hrachu, v dalších dnech již nebylo u většiny krav identifikovatelné. $V$ ojedinělých př́ipadech byl již 15 . až 17. den po porodu, $u$ více krav 18. -20. den po porodu patrný růst folikulu. Většina krav vykázala příznaky folikulárni fáze pohlavního cyklu ve čtvrtém týdnu po porodu a část byla v tomto období již v metestru nebo diestru. Morfologické změny prvního pohlavního cyklu byly zjištěny častěji na levém ovariu a na straně v předcházející graviditě neobřezlého děložního rohu.

Динамика изменений половых органов коров в позднем послеродовом периоде и в начале нового цикла воспроизводства с учетом восстановления овариальной активности, течки и первой послеродовой обуляции

У 282 коров породы чешской пеструшки в поздний послеродовой период и в начале нового цикла воспроизводства $(12-80$ суток после отела) проводились наблюдения за процессом инволюции матки, регрессией желтого тела, за восстановлением овариальной активности, проявлениями течки и первой послеродовой овуляцией.

Динамика инволюционных изменений половых органов, выьвленных вла- 
галищным и прямокишечным исследованием, не выходила за рамкй опубликованных информаций. Чаще всего забеременел правый угол матки, на 12 14 сутки после отела у части коров было явно установлено регрессивное желтое тело величиной с горошек, в последующие дни у большинства корош не было установлено. В отдельных случаях уже на 15-17 сутки после отела, у большего количества коров на $18-20$ сутки после отела, наблюдался явный рсст фолликула. Большинство коров отличалось признаками фолликулярной фазы полового цикла на четвертую неделю после отела и часть коров в данный период находилась уже в метәструсе или диэструсе. Морфологические изменения полового цикла были чаще всего установлены в левом яичнике и на стороне в предшествующей беременности не забеременелого угла матки.

\section{References}

ARBEITER, K.: Puerperalis zavarok hatása nöivaru szarvasmarha reprodukciós teljesítménvére. Mag. Állatorv. Lap., 31, 1976: 350-352.

BACH, S.: Puerperalverlauf und Eintritt der Konzeptionsbereitschaft in Rinderherden. Mh. Vet. Med., 29, 1974: 448-451.

BOSTEDT, H. - REISSINGER, H. - GÜNZLER, D.: Klinische Erhebungen über dem Verlauf der Puerperalperiode bei Rindern aus Bestanden mit Fertilitätsproblemen. Berl. Münch. t. Wschr., 89, 1976: 24-28.

BUCHHOLZ, G. W. - BUSCH, W.: Untersuchungen über Beziehungen zwischen ovarieller Aktivität und Uterusinvolution bei Kühen post partum. Mh. Vet. Med., 32, 1977: 95-97.

BUCHHOLZ, G. W. - JERICHOW, A.: Untersuchungen über Beziehung zwischen der Höhe der Milchleistung, der Milchkurventyp und Konzeptionsbereitschaft bei Kühen. Mh. Vet. Med., 32, 1977: 611-615.

GIER, H. T. - MARION, G. B. : Uterus of the Cow after Parturition. Involutional Changes. Am. J. Vet. Res., 29, 1968: 83-96.

KUDLÁC, E.: Hormonální stav a obnovení pohlavního cyklu u krav post partum. Živočišná výroba, 20, 1975: $271-277$.

KUDLÁC, E. - VLČEK, Z.: Klinické změny na pohlavním ústrojí a obsah bakterií v děloze po normálním porodu. Vet. Med., 15, 1970: 11-19.

LAKTIS, J.: Sledovanie puerpéria kráv a možnosti jeho ovplyvnenia lokálnym ošetrením maternice. Thesis VŠV Košice 1979, $173 \mathrm{p}$.

LLOYD, E. - MCMAHON, K. J. - GIER, H. T. - MARION, G. B.: Uterus of the Cow after Parturition. Bacterial Content. Am. J. Vet. Res., 29, 1968: 77-81.

MARION, G. B. - NORWOOD, J. S. - GIER, H. T.: Uterus of the Cow after Parturition. Factors Affecting Regression. Am. J. Vet. Res., 29, 1968: 71-75.

RÜSSE, M.: Beziehungen zwischen Uterusinvolution und Konceptionsfähigkeit beim Rind. Zuchthygiene, 3, 1968: 183-190.

WAGNER, W. C. - HANSEL, W.: Reproductive Physiology of the Post Partum Cow. I. Clinical and Histological Findings. J. Reprod. Fertility, 18, 1969: 493-500.

WAGNER, W. C. - SAATMAN, R. - HANSEL, W.: Reproductive Physiology of the Post Partum Cow. II. Pituitary Adrenal and Thyroid Function. J. Reprod. Fertility, 18, 1969: 501 to 508.

WOHANKA, K.: Zur Corpus-luteum-Enukleation bei brunstlosen Rindern. Mh. Vet. Med., 16, 1961: $725-730$. 